\title{
In silico study of curcumol, curcumenol, isocurcumenol, and $\beta$-sitosterol as potential inhibitors of estrogen receptor alpha of breast cancer
}

\author{
Resmi Mustarichie, Jutti Levitas, Jopi Arpina \\ Faculty of Pharmacy, Universitas Padjadjaran, Jatinangor, Indonesia
}

\begin{abstract}
Abstrak
Latar belakang: Berdasarkan data sistem informasi rumah sakit (SIRS) tahun 2007, kanker payudara menempati urutan pertama pada pasien rawat inap di seluruh rumah sakit di Indonesia. Reseptor estrogen alfa (ER $)$ diasosiasikan dengan kanker payudara sebab ditemukan dalam kadaryang tinggi dalam jaringan kanker. Kurkumol, kurkumenol, isokurkumenol dari rimpang temu putih (Curcuma zedoaria (Christm.) Roscoe), dan $\beta$-sitosterol dari biji labu kuning (Cucurbita pepo L.) dilaporkan memiliki aktivitas penghambatan terhadap sel kanker. Penelitian ini menampilkan studi komputasi dari senyawa-senyawa tersebut sebagai penghambat ERo.
\end{abstract}

Metode: Simulasi docking dilakukan pada laporan ini untuk memvisualisasikan interaksi tingkat molekuler antara keempat senyawa tersebut dengan ERo. Sebagai perbandingan, dilakukan pula simulasi docking antara estradiol dan tamoksifen terhadap ERo.

Hasil: Simulasi docking menunjukkan bahwa senyawa kurkumol, kurkumenol, isokurkumenol, dan $\beta$-sitosterol diprediksi memiliki potensi sebagai inhibitor reseptor estrogen alfa (ER ) berturut-turut dariyang terbaik adalah isokurkumenol, kurkumol, kurkumenol, dan $\beta$-sitosterol dengan nilai masing-masing 0,584 M, 1,36 M, 1,61 M, dan 7,35 M. Kurkumenol dan estradiol berinteraksi dengan ERa melalui ikatan hidrogen dan interaksi hidrofobik, sedangkan kurkumol, isokurkumenol, $\beta$-sitosterol, dan tamoxifen melalui interaksi dalam suksesi hidrofobik.

Kesimpulan: Bahan alam yang mengandung keempat senyawa ini memiliki potensi untuk dijadikan obat dan atau obat adjuvant pada terapi antikanker payudara.

\begin{abstract}
Background: Based on data from the Hospital Information System (HIS) in 2007, breast cancer is the top ranked diagnosed cancer in Indonesia. Estrogen receptor alpha $(\mathrm{ER} \alpha)$ is associated with breast cancer because it is found in high levels in cancer tissues. Curcumol, curcumenol, isocurcumenol of white tumeric rhizomes (Curcuma zedoaria (Christm.) Roscoe), and $\beta$-sitosterol from seeds of pumpkin (Cucurbita pepo L.) have been reported to have inhibitory activity against cancer cells. This study presents the in silico study of these compounds as inhibitors of $\mathrm{ER} \alpha$.
\end{abstract}

Methods: Docking simulations are carried out in this paper to visualize molecular-level interactions between the four compounds with ER $\alpha$. Docking simulations between estradiol and tamoxifen on ER $\alpha$ are carried out as well.

Results: Docking results indicated that curcumol, curcumenol, isocurcumenol, and $\beta$-sitosterol showed inhibitory activity againts estrogen receptor alpha $(\mathrm{ER} \alpha)$. The order of potency is shown consecutively by isocurcumenol, curcumol, curcumenol, and $\beta$-sitosterol with values $0.584 \mathrm{M}, 1.36 \mathrm{M}, 1.61 \mathrm{M}$, and $7.35 \mathrm{M}$ respectively. Curcumenol and estradiol interacts with ER $\alpha$ through hydrogen bonds and hydrophobic interactions, whereas curcumol, isocurcumenol, $\beta$-sitosterol and tamoxifen through hydrophobic interactions in succession.

Conclusion: Natural products containing all four compounds have the potential to be used as drugs or adjuvant drugs in breast cancer therapy.

Keywords: $\beta$-sitosterol, breast cancer, curcumol, curcumenol, estradiol, ER $\alpha$, isocurcumenol

pISSN: 0853-1773 • eISSN: 2252-8083 • http://dx.doi.org/10.13181/mji.v23i1.684 • Med J Indones. 2014;23:15-24

Correspondence author: Resmi Mustarichiei, resmi.mustarichie@unpad.ac.id

Copyright @ 2014 Authors. This is an open access article distributed under the terms of the Creative Commons Attribution-NonCommercial-ShareAlike 4.0 International License (http://creativecommons.org/licenses/by-nc-sa/4.0/), which permits unrestricted non-commercial use, distribution, and reproduction in any medium, provided the original author and source are properly cited. 
Based on the Hospital Information System (HIS) in 2007 , breast cancer is the top ranked diagnosed cancer in Indonesia. ${ }^{1}$ In 2010, medical records of Dharmais Cancer Hospital revealed that, the breast cancer is the most common cancer suffered by women.

Estrogen receptor alpha $(\mathrm{ER} \alpha)$ is associated with breast cancer and is overexpressed in cancer tissue. ${ }^{2}$ Estradiol (E2) or 17- $\beta$ estradiol, which is transduced through estrogen receptors, namely $\mathrm{ER} \alpha,{ }^{3}$ is an agonist of the estrogen receptor ER $\alpha$. Estradiol stimulation may affect the proliferation of breast cancer cells. ${ }^{4} \mathrm{ER} \alpha$ is a protein with a weight of $66 \mathrm{kDa}^{5}$ which has the amino acid constituent active pocket consisting of Met343, Leu346, Leu349, Ala350, Glu353, Trp383, Leu384, Leu387, Met388, Leu391, Arg394, Phe404, Met421, Ile424, Phe425, Leu428, His524, Leu525, and Gly529. ${ }^{6}$

Curcumol, curcumenol, and isocurcumenol is a sesquiterpene that is a constituent of the essential oil in white tumeric rhizomes. ${ }^{7}$ In vivo studies of ethanol extract of white tumeric rhizomes showed it has chemopreventive effects on mammary gland cells in dose of $300 \mathrm{mg} / \mathrm{kg} .{ }^{8}$ In vitro studies of the curcumol in concentration of $50 \mu \mathrm{g} / \mathrm{mL}$ showed it has an activity as a growth inhibitors of cervical cancer HeLa cells (80\%), breast cancer cells MCF-7 (74.57\%), breast cancer cells MM231 (75\%), and ovarian cancer cells OV-UL -2 (68.25\%). Further research showed that curcumol was able to inhibit the synthesis of RNA in HeLa cells, MCF-7, and MM231. ${ }^{9}$ Combination curcumenol and platicodin D showed inhibitory activity on the proliferation of breast cancer cells were better than each ingredient used alone. ${ }^{10}$

Sitosterol is a phytosterol that is widely available in pumpkin seeds. ${ }^{11}$ Pumpkin seed extract has been known to have several activities such as antidiabetic, antibacterial, anticancer, and antioxidant. Besides that, pumpkin seed oil is traditionally used as medicine in some countries such as China, Yugoslavia, Argentina, India, Mexico, Brazil, and the United States. ${ }^{12} \beta$-sitosterol acts as lowering cholesterol, ${ }^{13}$ prostate-cancer, and breast-cancer. ${ }^{14}$ In vitro studies of $\beta$-sitosterol in a concentration of $10 \mu \mathrm{M}$ showed inhibitory activity on MCF-7 with percentage of inhibition of $39 \% .^{15}$ This repot focus on in silico study of these compounds as inhibitors of estrogen receptor alpha $(\mathrm{ER} \alpha)$ by the fact that there is no similar report has been published elsewhere.

This study explored the interaction of curcumol, curcumenol, isocurcumenol, and $\beta$-sitosterol against
ER $\alpha$ through docking using ligand-based approach and the ligand used has been known having both in vitro and and in vivo biological activities.

\section{METHODS}

\section{Tool}

The hardware used for the calculations, molecular modeling and molecular docking include personal computer ACER ASPIRE 2920 with technical specifications of Intel Core 2 Duo CPU T5550 / 1.83 $\mathrm{GHz}$, system operation 7 Ultimate 32-bit Windows, a hard disk capacity of $320 \mathrm{~GB}$, and $2.0 \mathrm{~GB}$ of RAM.

The softwares used includes 3D ChemBio program package v.12.0.2Free Trial (Serial number: 186410320-7811), OpenBabel Program 2.1.1 (downloaded from http://openbabel.org/), HyperChem Program v8.0. Professional Edition (Verifi code: 0-28331), AutoDock Vina program (Molecular Graphics Laboratory, The Scripps Research Institute in 2011 downloaded from http://vina.scripps.edu/download. html), Program Tools v1.5.6 MGL (Molecular Graphics Laboratory, The Scripps Research Institute in 2012 downloaded from http://mgltools.scripps. edu), Ligand Explorer Viewer v.3.8 program (by the Research Collaboratory for Structural Bioinformatics, which is an online data from http://www.pdb.org/pdb/ explore) Q-SiteFinder program, which is a freeware online that are accessed from www.bioinformatics. leeds.ac.uk/qsitefi, The program PyMOL (The PyMOL Molecular Graphics System 2002 by Delano, WL downloaded from http:/www.pymol.org), ArgusLab Program v.4.0.1 (by Mark Thompson and the 2004 planaria Software downloaded from http:// www.arguslab.com).

The study began with the preparation of ER $\alpha$ (PDB code: 1A52) obtained from the Protein Data Bank (www.pdb.org). The preparation was done by downloading data from the Protein Data Bank ER $\alpha$, reduction $\mathrm{ER} \alpha$ chains into monomeric form using SwissPDBViewer v4.01, analysis binding pocket by Ligand Explorer Viewer bond in the Protein Data Bank (www.pdb.org) and Q-SiteFinder, analysis of ligand-receptor interactions with the Ligand Explorer Viewer in the Protein Data Bank (www.pdb.org).

Subsequently, preparation of ligand curcumol, curcumenol, isocurcumenol, $\beta$-sitosterol, estradiol, and tamoxifen were done by $3 \mathrm{D}$ ChemBio package v.12.0.2 Free Trial and HyperChem v8.0. Professional Edition. The ligand preparation was started by 
drawing 2D and 3D ligand structure using ChemBio program package 3D v.12.0.2 Free Trial, followed by optimization of geometry with HyperChem software v8.0. and Professional Edition and analysing of molecular properties with QSAR Properties on the program HyperChem v8.0. Professional Edition.

To verify, make sure that the AutoDockVina program used was valid, the model structure was overlayed with a ligand that had been crystallized using program HyperChem v8.0. Professional edition, redocking ligands had been crystallized into ER $\alpha$ binding pockets using the program AutoDock Vina and analysing of validation data.

Further, docking of curcumol, curcumenol, isocurcumenol, $\beta$-sitosterol, estradiol, and tamoxifen using AutoDock Vina program and last, interpretation of obtained data. All data has been carried out at least ten times with eight out of ten similar data. From figures and obatained data, we would be able to determine type of the binding and how strong its bound to ER $\alpha$.

\section{RESULTS}

Figures 1, figure 2, and table 1 were obtained from preparation of ER $\alpha$. Figure 1 showeds visualization of the results of the reduction of estrogen receptor alpha $(E R \alpha)$ of the form homodimer (chain A \& B) (a) to form monomer (chain A) (b) using the program AutoDock Vina, Figure 2 shows pockets active of ER $\alpha$ using Q-SiteFinder programme. Table 1 shows comparison of amino acid residues pocket compiling using active ER $\alpha$ ligand Explorer Viewer and Q-SiteFinder.

Results of preparation of ligand curcumol, curcumenol, isocurcumenol, $\beta$ - sitosterol, estradiol and tamoxifen with 3D ChemBio Program Package v.12.0.2 Free Trial and HyperChem v8.0. Professional Edition showed in figure 3 and tables 2.

Table 3 was obtained from validation programme and the results of redocking estradiol against ER $\alpha$ crystal.

Docking programme and interpretation data gave table 4 showing docking results of curcumol, curcumenol, isocurcumenol, $\beta$-sitosterol, estradiol, and tamoxifen against ER $\alpha$.

\section{DISCUSSION}

\section{Preparation ERa results were obtained from protein data bank}

ER $\alpha$ were downloaded from the Protein Data Bank with PDB code: 1A52 which was the result of crystallization form of proteins with the estradiol ligand crystal with a value of $2.8 \AA$ resolution. The receptor protein was a homodimer consisting of two units of the same monomers (chain ER $\alpha$. A and B). Both monomer could be used as a ligand binding site because it had the same amino acid composition. However, to focus on the areas that will be docked receptors, then selected one monomer, the chain A. Reduction was conducted using the program chain SwissPDBViewer v4.01 (Figure 1).
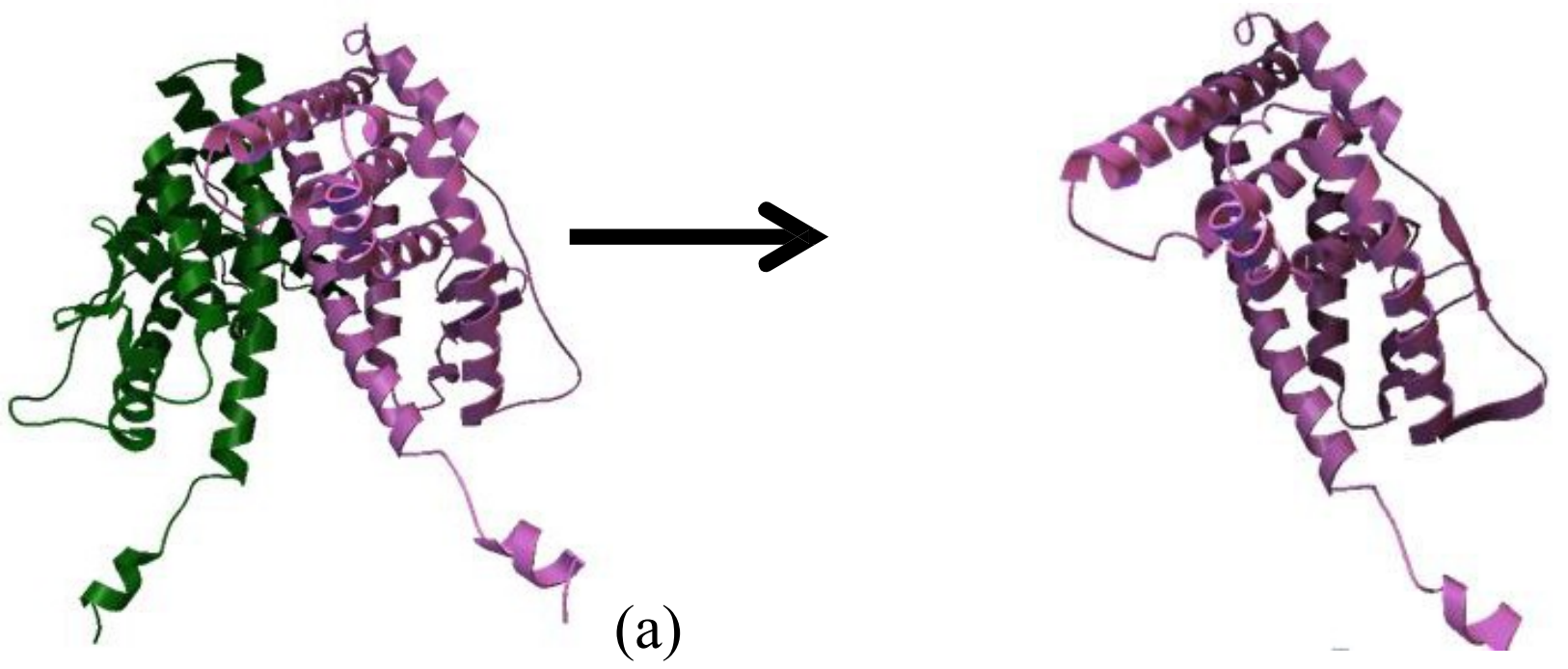

(b)

Figure 1. Visualization of the results of the reduction of estrogen receptor alpha (ER $\alpha$ ) of the form homodimer (chain A \& B) (a) to form monomer (chain A) (b) (drawn with the AutoDock Vina program) 
To determine the amino acid residues of he active $\mathrm{ER} \alpha$ pocket, it is necessary to analyze active pocket by recording amino acid residues bound with estradiol. Analyses were performed using the program Ligand Explorer Viewer and Q-SiteFinder (Figure 2). Except to determine amino acid residue, Q-SiteFinder can also examine the volume of protein and active pocket volume. A chain volume was found $23488 \mathrm{~A} 3 \mathrm{ER} \alpha$, whereas active pocket volume was $561 \mathrm{~A} 3$. Active pocket volume used to predict whether a ligand will be able to fit into the receptor as a whole or only in a part. From the analysis of molecular properties, it was known that the six compounds (curcumol, curcumeno, isocurcumenol, $\beta$-sitosterol, estradiol and tamoxifen) have a greater volume than the volume of active ER $\alpha$ pocket, so it could be predicted that the six compounds as a whole would not fir into the ER $\alpha$. But that does not mean that they can not produce biological activity, due to the fact that to activate a receptor (produce biological activity) does not have to enter the compound as a whole. In addition to volume, from Q-SiteFinder also obtained information about the coordinates of the minimum and maximum active pocket. Coordinates $(\mathrm{x}, \mathrm{y}, \mathrm{z})$ minimum active pocket (site 1) located at 95,15 , and 96, while the maximum was located at coordinates 115,35 , and 113 . The area between the minimum and maximum coordinates of the area was active. These coordinates was used to determine the grid to be used in the docking process.

Comparison of the amino acid residues of the active pocket ER $\alpha$ Ligand Explorer Viewer using Q-SiteFinder and can be seen in table 1. Table 1 showed the similarity of amino acid residues that were known by Ligand Explorer and Q-SiteFinder, which could be concluded that the amino acid residues were amino acid residues making up the active ER $\alpha$ pocket Number of amino acids in the Q-SiteFinder more numerous than Ligand Explorer Viewerwhich caused by a wider observation range. Its analysis was based on the principle of the interaction energy between macromolecules with a van der Waals loop to fi pockets that are considered the most favored binding by the ligand from the energy point of view (ie, pocket bonding interactions lowest energy). Whereas in the Ligand Explorer Viewer, amino acid residues crystals obtained from ligand-receptor interactions, thus

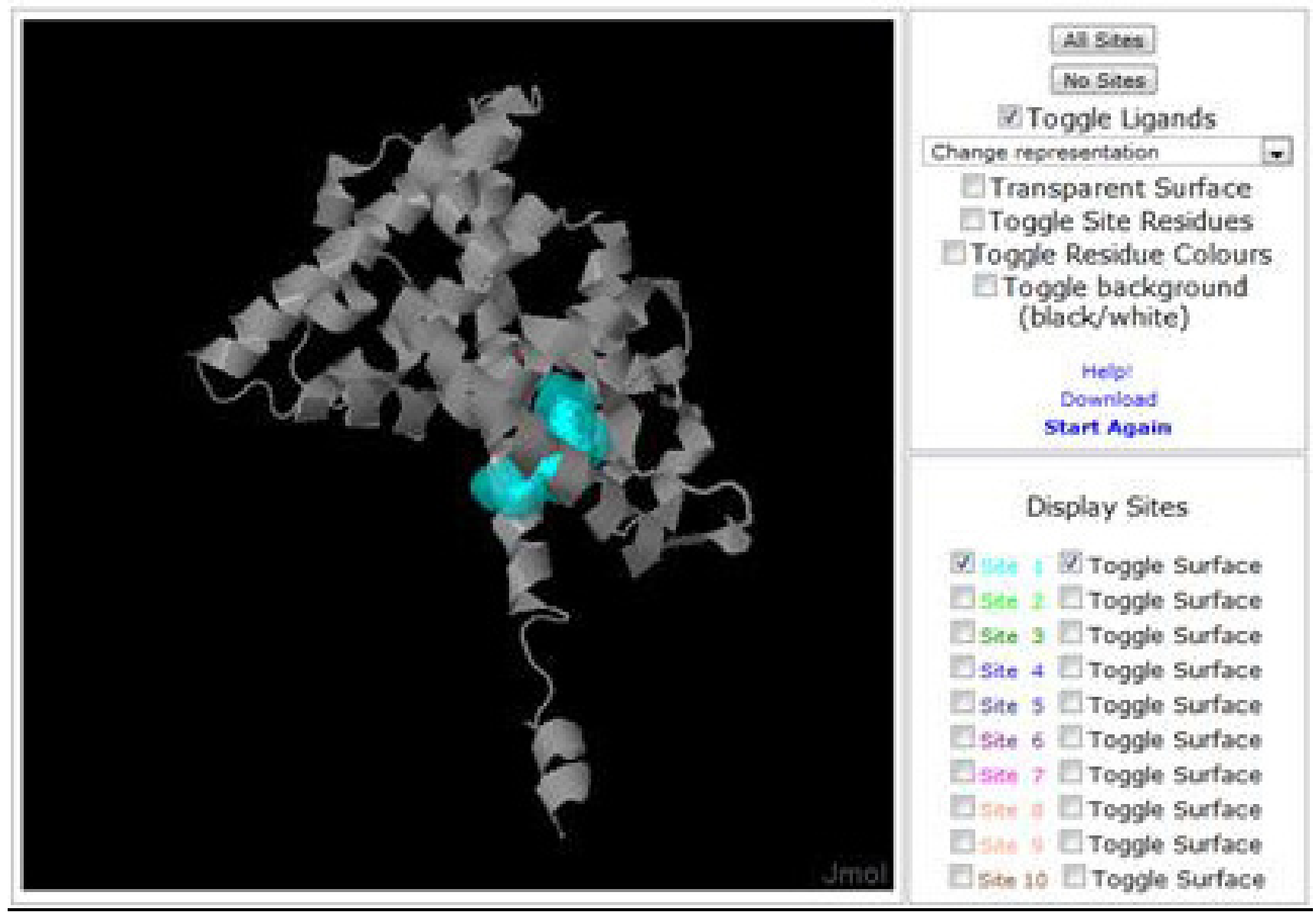

Figure 2. Pockets active of Era (drawn with Q-SiteFinder programme) 
narrower range observations. Therefore, the amino acid residues in the Q-SiteFinder clearer than Ligand Explorer Viewer.

Based on the analysis of ligand-receptor binding with Ligand Explorer Viewer, estradiol formed hydrogen bonds and hydrophobic interactions with ER $\alpha$. Amino acids that formed hydrogen bonds with estradiol were Glu353, Arg394, and His524. While the amino acids that formed the hydrophobic interactions with the estradiol were Ala350, Leu387, Met388, Leu391, Phe404, Ile424, and Leu525.

Preparation of ligand curcumol, curcumenol, isocurcumenol, $\beta$-sitosterol, estradiol and tamoxifen with 3D ChemBio Program Package v.12.0.2 Free Trial and HyperChem v8.0. Professional Edition.

Preparation of ligands included the creation of 2D and 3D structure, geometry optimization, and analysis of the properties of 2D and 3D molekul. Structure created using 3D ChemBio program v.12.0.2 Free Trial. Figure 3 shows 2D-3D structures of curcumol, curcumenol, isocurcumenol, estradiol, $\beta$-sitosterol, and tamoxifen.

The optimized geometry of the 3D structure was done in order to obtain the most stable conformation with the lowest energy value (global minima). The compounds that have been optimized geometry was then analyzed by QSAR Properties nature in HyperChem program v8.0. Professional Edition. Results of analysis curcumol molecular properties, curcumenol, isocurcumenol, estradiol, $\beta$-sitosterol and tamoxifen are displayed in table 2 .

As shown in table 2, the energy of the six compounds was negative, it indicated the six compounds were in a stable conformation, which was similar to the real situation in nature. To determine the feasibility of an oral drug candidate route, as a reference Lipinski'sRule of Five. ${ }^{16}$ This rule describes the important properties of a molecule from pharmacokinetics point of view.

Value ${ }^{c} \log \mathrm{P}$ (calculation $\log \mathrm{P}$ ) indicates the value of $\log \mathrm{P}$ (lipophilicity) resulting from the calculation of computing. Value clog $\mathrm{P}$ is proportional to the value of $\log$ P. Value of $\log$ P of a compound to be developed as a drug route orally must meet the value required by Lipinski's Rule of Five i.e $-2<\log \mathrm{P}<5$. $\beta$-sitosterol had value ${ }^{c} \log \mathrm{P}$ value is the greatest, thus this compound is predicted to have tendency to bind strongly to the cell membrane, thereby decreasing its bioavailability.

Table 1. Comparison of amino acid residues pocket compiling, data obtained using active ER $\alpha$ ligand explorer viewer and QSiteFinder

\begin{tabular}{|c|c|c|}
\hline Amino Acids & Ligand Explorer & $Q$-SiteFinder \\
\hline Met 343 & $\sqrt{ }$ & $\sqrt{ }$ \\
\hline Leu 346 & $\sqrt{ }$ & $\sqrt{ }$ \\
\hline Thr 347 & - & $\sqrt{ }$ \\
\hline Leu 349 & - & $\sqrt{ }$ \\
\hline Ala 350 & $\sqrt{ }$ & $\sqrt{ }$ \\
\hline Asp351 & - & $\sqrt{ }$ \\
\hline Glu 353 & $\sqrt{ }$ & $\sqrt{ }$ \\
\hline Trp 383 & - & $\sqrt{ }$ \\
\hline Leu 384 & - & - \\
\hline Leu 387 & $\sqrt{ }$ & $\sqrt{ }$ \\
\hline Met 388 & $\sqrt{ }$ & $\sqrt{ }$ \\
\hline Leu 391 & $\sqrt{ }$ & $\sqrt{ }$ \\
\hline Arg 394 & $\sqrt{ }$ & $\sqrt{ }$ \\
\hline Phe 404 & $\sqrt{ }$ & $\sqrt{ }$ \\
\hline Met 421 & - & $\sqrt{ }$ \\
\hline Ile 424 & $\sqrt{ }$ & $\sqrt{ }$ \\
\hline Phe 425 & - & $\sqrt{ }$ \\
\hline Leu 428 & - & $\sqrt{ }$ \\
\hline His 524 & $\sqrt{ }$ & - \\
\hline Leu 525 & $\sqrt{ }$ & - \\
\hline
\end{tabular}

Table 2. Results analysis of the nature of molecular properties QSAR in HyperChem program v8.0. Professional Edition

\begin{tabular}{lcccc}
\hline Compound & $\begin{array}{c}\text { Energy } \\
\left(\mathrm{Kcal}^{-m^{-1}}\right)\end{array}$ & clog P & Volume $(\AA)$ & Mass (amu) \\
\hline Curcumol & -4035.4670 & 3.22 & 747.63 & 236.35 \\
Curcumenol & -3795.3121 & 3.08 & 765.86 & 234.34 \\
Isocurcumenol & -3907.8750 & 2.78 & 744.41 & 234.34 \\
$\beta$-sitosterol & -7745.6036 & 7.9 & 1303.76 & 414.72 \\
Estradiol & -4549.3646 & 4.01 & 811.98 & 272.39 \\
Tamoksifen & -6181.2997 & 5.63 & 1211.00 & 387.52 \\
\hline
\end{tabular}



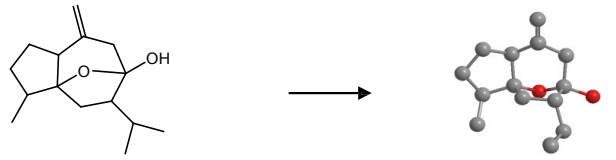

(A-1)<smiles>CC1=CC23CCC(C)C(CC2=C(C)C)(O3)C1O</smiles>

(B-1)

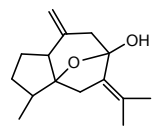

$(\mathrm{C}-1)$<smiles>CCC(C)CCCC(C)C12CCC3C4CC=C5CC(O)CCC5(CCC1C43C)C2C</smiles>

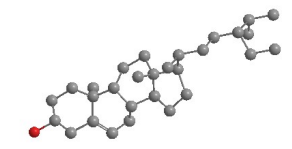

(D-1)

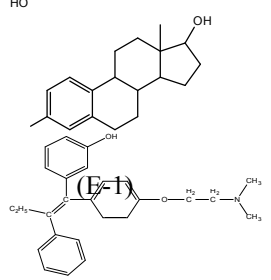

(F-1)
$(\mathrm{A}-2)$

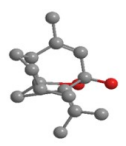

(B-2)

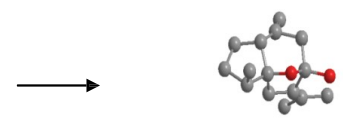

(C-2)
Figure 3. 2D structure of (A-1) curcumol,

(C-1) isocurcumenol, (D-1) $\beta$-Sitosterol, (E-1) Estradiol, (F-1) Tamoxifen, and 3D structure of (A-2) curcumol, (B-2) curcumenol, (C-2) isocurcumenol, (D-2) $\beta$-Sitosterol, (E-2) Estradiol, (F-2) Tamoxifen (drawn with ChemBio 3D v.12.0.2 Free Trial)

The six compounds have mass more than $500 \mathrm{amu}$, corresponding to Lipinski's Rule of Five. The mass of a compound showed the ability to penetrate the membrane. If it is too large, then the compound will have difficulty to penetrate the membrane. Six compounds possessed volume were greater than the volume of the active pockets $\operatorname{ER} \alpha\left(561 \mathrm{~A}^{0}\right)$, so that these six compounds were expected to be difficult to enter into the overall ER $\alpha$.

Other molecular properties which determine the feasibility of a compound to be developed as a drug by oral route Lipinski's Rule of Five, is the number of hydrogen bond donors and acceptors. According to Lipinski's Rule of Five, a compound can be used as a drug by oral route if the donor has a maximum of five and ten hydrogen bond acceptors. The number of hydrogen bond donors and acceptors curcumol, curcumenol, isocurcumenol, $\beta$-sitosterol, estradiol, and tamoxifen are fulfilled Lipinski's Rule of Five. Hydrogen bond donor $\mathrm{H}$ atom is bound to electronegative atoms such as $\mathrm{N}$ or $\mathrm{O}$. While the hydrogen bond acceptor is an electronegative atom, which has a lone pair as atomic $\mathrm{O}$ and $\mathrm{N}$. Hydrogen bond donor and acceptor is an asset to the formation of hydrogen bonds between the six compounds with amino acid residues making up the pocket active ER $\alpha$.

\section{Validation program AutoDock Vina}

Validation aims to ensure that installed AutoDock Vina program had compatibility with used hardware as the hardware normally had different specifi Validation program AutoDock Vina done with overlay and redocking.

Table 3. Results analysis of the nature of molecular properties QSAR in HyperChem Program v8.0. Professional Edition

\begin{tabular}{|c|c|c|c|c|}
\hline \multirow{2}{*}{ Repetition } & \multicolumn{4}{|c|}{ Parameter } \\
\hline & EI & KI & $\begin{array}{l}\text { Hidrogen } \\
\text { Bond }\end{array}$ & AAR \\
\hline 1 & -10.6 & 0.0168 & $\begin{array}{c}\text { H-Est...O- } \\
\text { Glu353 } \\
\text { O-Est...H- } \\
\text { Arg394 } \\
\text { O-Est...H- } \\
\text { His524 }\end{array}$ & $\begin{array}{l}\text { Glu353, } \\
\text { Leu387, } \\
\text { Met388, } \\
\text { Leu391, } \\
\text { Arg394, } \\
\text { Ile424, } \\
\text { His524, } \\
\text { Leu525 }\end{array}$ \\
\hline 2 & -10.6 & 0.0168 & $\begin{array}{c}\text { H-Est...O- } \\
\text { Glu353 } \\
\text { O-Est...H- } \\
\text { Arg394 } \\
\text { O-Est...H- } \\
\text { His524 }\end{array}$ & $\begin{array}{l}\text { Glu353, } \\
\text { Leu387, } \\
\text { Met388, } \\
\text { Leu391, } \\
\text { Arg394, } \\
\text { Ile424, } \\
\text { His524, } \\
\text { Leu525 }\end{array}$ \\
\hline 3 & -10.6 & 0.0168 & $\begin{array}{c}\text { H-Est...O- } \\
\text { Glu353 } \\
\text { O-Est...H- } \\
\text { Arg394 } \\
\text { O-Est...H- } \\
\text { His524 }\end{array}$ & $\begin{array}{l}\text { Glu353, } \\
\text { Leu387, } \\
\text { Met388, } \\
\text { Leu391, } \\
\text { Arg394, } \\
\text { Ile424, } \\
\text { His524, } \\
\text { Leu525 }\end{array}$ \\
\hline
\end{tabular}

Notes :

EI: Energy interaction (Kcal/mol)

KI: Inhibition constants $(\mu \mathrm{M})$

AAR: Amino acid residues 
Overlay conducted between ligand crystal ligand model. Ligand estradiol crystals were isolated from the crystal-ER $\alpha$ ligand complex. While the model ligand was estradiol made in the form of $2 \mathrm{D}$ and $3 \mathrm{D}$ were then optimized geometry. The results of the model ligand optimization then stacked (overlay) with the ligand crystal and seen the value of RMSD (Root Mean Square Deviation) it. Overlay performed in three repetitions. RMSD values resulting the average of $0.34 \AA$. RMSD value more than $2 \mathrm{~A}$ shows the validity of a program. ${ }^{17}$

The overlay, validation can also be known through redocking, the process by which ligand crystal that has been isolated from a receptor in docking back into the receptor active pocket. Results redocking crystalline estradiol to ER $\alpha$ pocket is summarized in table 3 .

Amino acid residues of redocking results were then compared with the results of Ligand Explorer Viewer. Comparison of results redocking amino acid residues with the Ligand Explorer Viewer shows AutoDock Vina redocking gave a slight shift in the position of the ligand. It shown from the slight differences in amino acid residues in the Ligand Explorer Viewer with redocking results, in which amino acid residues in the Ligand Explorer Viewer redocking more than the outcome. Shift in the position of the ligand was also evident from the number of hydrogen bonds, wherein the Ligand Explorer Viewer hydrogen bonds that formed four bonds, namely the amino acid Glu353 (two hydrogen bonds), Arg394, and His524 while redocking with AutoDock Vina resulted only produces three hydrogen bonds namely Glu353, Arg394, His524. So, in this case type of binding could be reproduced, but a shift in the position of the ligand. Docking results were able to reproduce the type of binding but showed ligand shift position was classifi as a near category, ${ }^{18}$ therefore it can be concluded that in this study the results of using the docking software AutoDock Vina grouped under the category of "near".

\section{Results of docking curcumol, curcumenol, isocurcumenol, $\beta$-sitosterol, estradiol, and tamoxifen using AutoDock program Vina and data interpretation}

Docking is a ligand placement technique into a pocket active receptor, which is a major step in computational studies to determine the level of interaction of a compound with the receptor. In this study, curcumol, curcumenol, isocurcumenol, and $\beta$-sitosterol was a tested ligand, estradiol as a natural ligand, whereas tamoxifen as a synthetic ligand.

In this docking grid box made variations which is aimed to obtain optimum conditions for ligand interaction with reseptor. Grid box was an area where the ligand interacts with the active receptor pocket. Size of the grid box that will be tailored to the ligand in the docking, where the size should be larger than the volume of the ligand to be docked. This was done in order to obtain maximum ligandreceptor interactions. However, the size of the grid box should not too big because it was feared the ligand binds to the amino acids that are not constituent of active receptor pocket so the results were not accurate. Variations of grid box used were $15 \times 15 \times 15,15 \times 15 \times 20,15 \times 20 \times 15,20 \times 15 \times 15$, $20 \times 15 \times 20$, and $20 \times 20 \times 15$. From six grid box one of the best grid box, which was selected could produce optimal docking parameters. Retrieval grid box was best done by docking six compounds in each grid box variation with repetition as much as ten times and taken the three best. Grid was the best box $20 \times 20 \times 15$, so the sixth compound docking was done at this grid box with ten repetitions and taken the three best. Results of docking curcumol, curcumenol, isocurcumenol, $\beta$-sitosterol, estradiol, and tamoxifen are shown in table 4.

Table 4 showed some of the parameters used to analyze ligand-receptor interactions, such as the interaction energy (EI), inhibition constants (Ki), hydrogen bonds, and amino acid residues. Interaction energy (EI) is the energy required by a ligand to enter and interact with the receptor. EI of sixth compound was negative. It showed that the six compounds were able to interact easily with ER $\alpha$. The smaller the value of EI, the easier entry and ligand binds to the receptor. EI value from the best was -10.7 $\mathrm{kcal} / \mathrm{mol},-8.5 \mathrm{kcal} / \mathrm{mol},-8.3 \mathrm{kcal} / \mathrm{mol},-8.0 \mathrm{kcal} /$ $\mathrm{mol},-7.9 \mathrm{kcal} / \mathrm{mol}$, and $-7.0 \mathrm{kcal} / \mathrm{mol}$ for estradiol, isocurcumenol, tamoxifen, curcumol, curcumenol, and $\beta$-sitosterol, respectively.

Inhibition constants $(\mathrm{Ki})$ suggested the potential of a compound. The smaller the value of $\mathrm{Ki}$ value, the smaller of the concentration of compound which is required to interact with its receptor. $\mathrm{Ki}$ value is directly proportional to EI. Experimental $\mathrm{Ki}$ values in the range of $10^{-12}$ to $10^{-2} \mathrm{M}$ (Bohm and Schneider, 2003). Ki values from the best that was, $0,014 \mu \mathrm{M}$, $0,584 \mu \mathrm{M}, 0,82 \mu \mathrm{M}, 1,36 \mu \mathrm{M}, 1,61 \mu \mathrm{M}$ and $7,35 \mu \mathrm{M}$ 
Table 4. Docking results curcumol, curcumenol, Isocurcumenol, $\beta$-sitosterol, estradiol, and tamoxifen against ER $\alpha$

\begin{tabular}{|c|c|c|c|c|}
\hline \multirow{2}{*}{ Ligands } & \multicolumn{4}{|c|}{ Parameter } \\
\hline & EI & KI & Hidrogen bond & AAR \\
\hline Curcumol & -8.0 & 1.36 & - & $\begin{array}{l}\text { Met343, Leu346, Thr347, Ala350, Leu384, } \\
\text { Leu387, Phe404, Met421, Leu428 }\end{array}$ \\
\hline Curcumenol & -7.9 & 1.61 & H-Cur...O-Leu346 & $\begin{array}{l}\text { Leu346, Ala350, Leu384, Leu387, Met388, } \\
\text { Leu391, Phe404, Leu428 }\end{array}$ \\
\hline Isocurcumenol & -8.5 & 0.584 & - & $\begin{array}{l}\text { Leu346, Leu349, Ala350, Leu384, Leu387, } \\
\text { Met388, Phe404, Leu525 }\end{array}$ \\
\hline$\beta$-sitosterol & -7.0 & 7.35 & - & $\begin{array}{l}\text { Leu346, Thr347, Ala350, Asp351, Leu354, } \\
\text { Trp383, Leu384, Leu387, Met388, Phe404, } \\
\text { Ile424, Leu428, Leu525, Lys529 }\end{array}$ \\
\hline Estradiol & -10.7 & 0.014 & $\begin{array}{l}\text { O-Est...H-Arg394 } \\
\text { O-Est...H-His524 }\end{array}$ & $\begin{array}{l}\text { Glu353, Met388, Leu391, Arg394, His524, } \\
\text { Leu525 }\end{array}$ \\
\hline Tamoxifen & -8.3 & 0.82 & - & $\begin{array}{l}\text { Leu346, Thr347, Ala350, Trp383, Met388, } \\
\text { Phe404, Met421, Ile424, Phe425, Leu428, } \\
\text { Leu525, Lys529 }\end{array}$ \\
\hline
\end{tabular}

Notes :

EI: Energy interaction $(\mathrm{Kcal} / \mathrm{mol})$

KI: Inhibition constants $(\mu \mathrm{M})$

AAR: Amino acid residues

for estradiol, isocurcumenol, tamoxifen, curcumol, curcumenol, and $\beta$-sitosterol, respectively.

Based on the EI and $\mathrm{Ki}$ values, the sixth active compound can occupy pocket ER $\alpha$. Isocurcumenol is a test compound that has the lowest $\mathrm{Ki}$ and $\mathrm{EI}$ values, suggesting that this compound/ is the most easiest to occupy into the active $\mathrm{ER} \alpha$ pocket.

Evaluation of docking results can also be observed from the interaction between the ligand-reseptor. The interaction formed including hydrogen bonds and hydrophobic interactions between the ligand formed by amino acid residues making up the active ER $\alpha$ pocket. Hydrogen bonds occur between $\mathrm{H}$ atoms attached to electronegative atom with an electronegative atom with a bond distance $1,72-2.85 \AA$, whereas hydrophobic interactions are formed between the drug molecules with nonpolar nonpolar regions receptors with bond distances of less than $4 \mathrm{~A}^{\mathrm{o}} .{ }^{19}$

Curcumol interacted with ER $\alpha$ through hydrophobic interaction. Hydrophobic interactions were formed between the amino acids Met343 curcumol (3.6 $\AA$ ), Leu346 (3.5 ^), Ala350 (3.7 to $3.9 \AA$ ), Leu387 (3.7 $\AA$ ), Phe404 (3.5 to $3.9 \AA$ ), Met421 (3.7 $\AA)$, Leu428 (3.6 $\AA)$.

Curcumenol interacted with ER $\alpha$ through hydrogen bonds and hydrophobic interactions. Hydrogen bond was formed between the $\mathrm{H}$ atom of curcumenol with $\mathrm{O}$ atoms of the amino acids Leu346 (1.952 $\AA$ ). In this case, curcumenol act as a donor and the amino acid leucine acts as a hydrogen bond acceptor. Hydrophobic interactions are formed between curcumeno and the amino acids of Ala350 (3.5 to 3.6 $\AA)$, Leu384 (3.3 A), Leu387 (3.6 - $3.7 \AA$ ), Met388 (3.5 ̊), Leu391 (3.3 - $3.8 \AA$ ), Phe404 (3.6 to $3.8 \AA$ ), and Leu428 (3.4 $\AA$ ).

Isocurcumenol interacted with ER $\alpha$ through hydrophobic interactions. Isocurcumenol hydrophobic interactions formed between isocurcumenol and the amino acids of Leu349 (3.6 to $3.8 \AA$ ), Ala350 (3.7 $\AA$ ), Leu384 (3.4 to $3.9 \AA$ ), Leu387 (3.5 to $3.9 \AA$ ), Met388 (3.5 to $3.7 \AA$ ), Phe404 (3.3 to $3.9 \AA$ ), and Leu525 (3.6 ̊).

$\beta$-sitosterol interacted with ER $\alpha$ through hydrophobic interactions. Hydrophobic interactions formed between the $\beta$-sitosterol and the amino acids of Leu346 (3.2 to $3.9 \AA$ ), Thr347 (3.4 to $3.7 \AA$ ), Ala350 (3.3 to $3.8 \AA$ ), Leu354 (3.4 to $3,9 A), \operatorname{Trp} 383$ (3.0 to $3.9 \AA$ ), Leu384 (3.4 to $3.7 \AA$ ), Leu387 (3.4 to $3.7 \AA$ ), Met388 (3.5 to $3.7 \AA$ ), Phe404 (3.5 - $3.8 \AA$ ), Ile424 (3.3 to $3.8 \AA$ ), and Leu525 (3.2 to $3.5 \AA$ ).

Interaction between the ligand comparison with $\mathrm{ER} \alpha$ is also noteworthy. Estradiol interacts with ER $\alpha$ through hydrogen bonds and hydrophobic 
interactions, whereas tamoxifen only hrough hydrophobic interaction. Hydrogen bonds were formed between atoms in estradiol estradiol with the $\mathrm{O}$ of $\operatorname{Arg} 394 \mathrm{H}$ atoms $(2.191 \AA)$ and the $\mathrm{O}$ atoms with $\mathrm{H}$ atoms His524 estradiol (2.196 $\AA$ ). In the formation of this hydrogen bond, estradiol acts as an acceptor, whereas amino acid (Arg394 and His524) acts as a donor. Estradiol interacts with hydrophobic amino acids Met388 (3.8 ̊), Leu391 (3.6 - $3.9 \AA$ ), and Leu525 (3.8 $\AA$ ). Tamoxifen interacted with hydrophobic amino acids Leu346 (3.5 - $3.8 \AA)$, Ala350 (3.7 to $3.9 \AA$ ), $\operatorname{Trp} 383$ (3.2 to $3.7 \AA$ ), Phe404

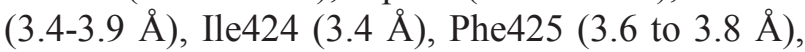
and Leu428 (3.6-3.7 $\AA)$.

Presence of the above amino acids at the test compound in the docking with ER $\alpha$ as can be explain in Figure 4. Figure 4 shows the results of docking between $\beta$-sitosterol with ER $\alpha$. As shown, the amino acid residues of: Leu346, Thr347, Ala350, Asp351, Leu354, Trp383, Leu384, Leu387, Met388, Phe404, Ile424, Leu428, Leu525 were detected.

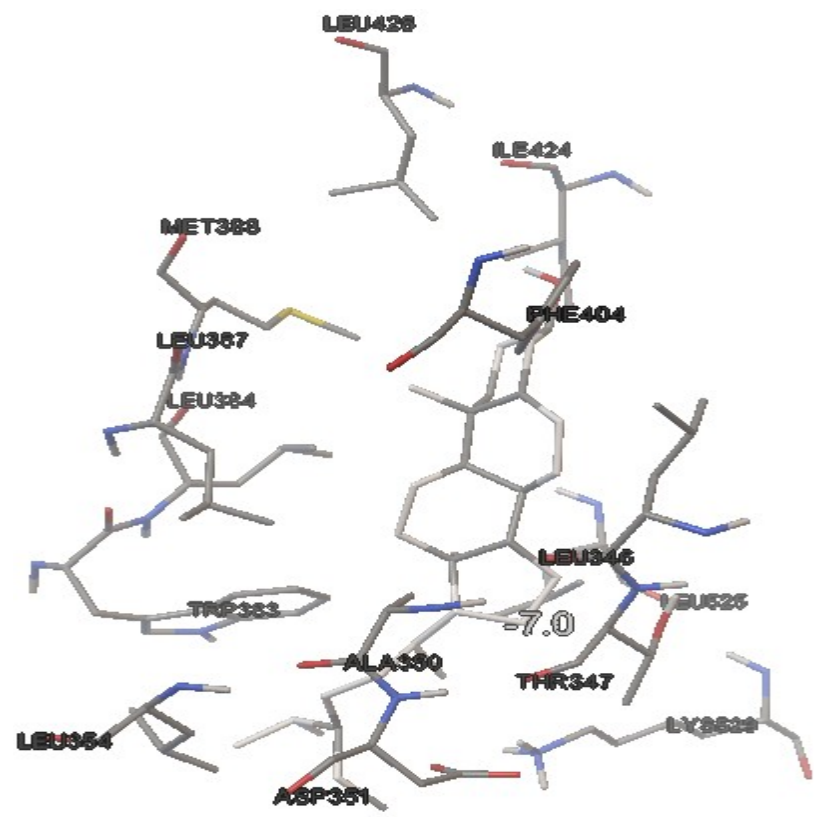

Figure 4. Docking results of $\beta$-sitosterol on ER $\alpha$

Most likely the amino acids residues could inhibit $\mathrm{ER} \alpha$ due to its steric hindrance effect. Overall results suggest natural products containing all four compounds have the potential to be used as medicine or adjuvant drug in anti-breast cancer therapy due to their activity against receptor ER $\alpha$.
We have reported ${ }^{20}$ that some compounds that are inhibitors activity against receptor ER $\alpha$ means that the compound can also act as an anti-infl drug that is caused by the cancer itself. This means that these compounds are predicted as antiinfl or as an adjuvant to cancer treatment drugs. The close relationship between infl and cancer has been described by Mantovani. ${ }^{21}$

In conclusion, all the test compounds, namely curcumol, curcumenol, isocurcumenol of white tumeric (Curcuma zedoaria (Christm.) Roscoe), $\beta$-sitosterol from pumpkin seeds (Cucurbita pepo L.), and the comparator compounds, estradiol and tamoxifen can occupy active pocket ER $\alpha$. Curcumenol and estradiol interacts with ER $\alpha$ through hydrogen bonds and hydrophobic interactions, whereas curcumol, isocurcumenol, $\beta$-sitosterol and tamoxifen interact through interactions in succession hydrophobic. Constanta of inhibition of the compound are $0.584 \mu \mathrm{M}, 1.36$ $\mu \mathrm{M}$, and $1.61 \mu \mathrm{M}$ for isocurcumenol, curcumol and curcumenol, respectively. Consequently, these predictions support that the natural products containing all four compounds have the potential to be used as medicine or adjuvant drug in anti-breast cancer therapy.

This study recommends that further research on toxicity data of the four compounds especially isocurcumenol as its has $\mathrm{EI}$ and $\mathrm{Ki}$ closer to tamoxifen for the search for breast anti-cancer drug.

\section{Conflict of interest}

The authors declare that this study is free of conflict of interest.

\section{REFERENCES}

1. Departemen Kesehatan Republik Indonesia. Profil Kesehatan Indonesia 2008. Jakarta: Departemen Kesehatan Republik Indonesia. 2009; 66. Indonesian.

2. Ikeda K, Inoue S. Estrogen receptor and their downstream targets in cancer. Arc Histol Cytol. 2004;67(5):435-42.

3. Murphy AJ, Guyre PM, Wira CR, Pioli PA. Estradiol Regulates Expression of Estrogen Receptor ERa46 in Human Macrophages. PLoS ONE. 2009;4(5):1-11.

4. Clemons M, Goss P. Estrogen and the Risk of Breast Cancer. N Engl J Med. 2001;344:276-85.

5. Lin CY, Strom A, Vega VB, Kong SL, Yeo AL, Thomsen JS, et al. Discovery of estrogen receptor a target genes and response elements in breast tumor cells. Genome Biol. 2004;5(9):R66. 
6. Tanenbaum D, Wang Y, Williams SP, Sigler PB. Crystallographic comparison of the estrogen and progesterone receptor's ligand binding domains. Proc Natl Acad Sci USA. 1998;95(11):5998-6003.

7. Khine $M$ M. Isolation and characterization of phytoconstituents from Myanmar medicinal plants. [disertation]. Wittenberg: Der Martin Luther Universität Halle; 2006.

8. Hamid IS. Histopatologi dan aktivitas proliferasi sel kelenjar mammae setelah pemberian ekstrak rimpang temu putih curcuma zedoaria dan inisiasi DMBA (Dimethylbenz (a) antrasen) pada tikus galur sprague dawley. Veterineria Medika. 2008;1(3):93-8. Indonesian.

9. Xu LC, Bian KJ, Liu ZM, Zhou J, Wang G. The inhibitory effect of curcumol on women cancer cells and synthesis of RNA. Tumor. 2005;25(6):570-2.

10. Han XH, Ye YY, Guo BF, Liu S. Effects of platycodin D in combination with different active ingredients of Chinese herbs on proliferation and invasion of 4T1 and MDAMB-231 breast cancer cell lines. Zhong Xi Yi Jie He Xue Bao. 2012;10(1):67-75. Chinese.

11. Chevallier A. The Encyclopedia of Medicinal Plants. London: Wolfe Publishing Ltd; 1996.

12. Ardabili AG, Farhoosh G, Khodaparast MHH. Chemical composition and physicochemical properties of pumpkin seeds (Cucurbita pepo Subsp. Pepo Var. Styriaka) Grown in Iran. J Agr Sci Tech. 2011;13:1053-63.

13. Matsuoka K, Nakazawa T, Nakamura A, Honda C, Endo K, Tsukada M. Study of thermodynamic parameters for solubilization of plant sterol and stanol in bile salt micelles Chem Phys Lipids. 2008;154(2):87-93.

14. Awad AB, Barta SL, Fink CS, Bradford PG. $\beta$-Sitosterol enhances tamoxifen effectiveness on breast cancer cells by affecting ceramide metabolism. Mol Nutr Food Res. 2008;52(4):419-26.

15. Chai JW, Kuppusamy UR, Kanthimathi MS. Betasitosterol Induces Apoptosis in MCF-7 Cells. Malaysian Journal of Biochemistry and Molecular Biology 2008;16(2):28-30.

16. Lipinski CA, Lombardo F, Dominy BW and Feeney PJ. 2001. Experimental and computational approaches to estimate solubility and permeability in drug discovery and development settings. Adv Drug Deliv Rev. 2001;46(1-3):3-26.

17. Kontoyianni M, McClellan LM, Sokol GS. Progress in Medicinal Chemistry. J. Med. Chem. 2004;36:63-4.

18. Jones G, Willet P, Glen RC, Leach AR, Taylor R. Development and validation of a genetic algorithm for flexible docking. J Mol Biol. 1997;267(3):727-48.

19. Bohm HJ, Schneider G. Protein-ligand interactions from molecular recognition to drug design. Weinheim: WileyVCH. 2003.p.38-9.

20. Mustarichie R, Saptarini NM, Levita J. The Study of the interaction of quercetin and casticin with $\mathrm{H} 4 \mathrm{r}$, antiinflammatory receptor, as supporting data for antiinflammatory herbal medicine. Journal of Computer Science, Technology and Application. 2012;1(1):70-76.

21. N, Triaspolitica. "Kanker Payudara: Informasi, Penyebab, Gejala, Stadium Dan Pengobatan." Mau Nanya Dong Dok. N.p, 28 June 2017. Web. 30 June 2017. <https:// nanyadongdok.blogspot.com/2017/06/kanker-payudarainformasi-penyebab.html>. 